\title{
Analisis Perilaku Anggota Koperasi dalam Pembelian Barang pada KUD Karya Agung Kecamatan Singingi Kabupaten Kuantan Singingi
}

\author{
M. Irwan \\ Program Studi Akuntansi Fakultas Ilmu Sosial UNIKS Teluk Kuantan Riau \\ Muhdirwan120583@gmail.com
}

\section{ABSTRACT}

This research was conducted at KUD Karya Agung located in Sumber Datar Village, Kec. Singingi Kab. Kuantan Singingi. The purpose of this study is to determine what factors influence the behavior of cooperative members in making decisions to buy goods at KUD Karya Agung. While the benefits that the author can provide to cooperatives are as input or information for KUD Karya Agung management regarding the behavior of cooperative members in making decisions to buy goods offered by cooperatives.Based on the formulation of the problem and the purpose of the study, the authors propose a hypothesis that is suspected of the behavior of cooperative members in making decisions to buy goods in the KUD Karya Agung influenced by factors of culture, social class, attitude and psychology. From the research conducted by the author, an opportunity can be taken that the factors that influence the behavior of cooperative members in making decisions to buy goods at KUD Karya Agung are social environmental factors, attitudes and psychology.

Keywords: $\quad$ Member Behavior, Decision Making, Culture, Social Classes, Attitudes and Psychology

\section{ABSTRAK}

Penelitian ini dilaksanakan di KUD Karya Agung yang berkedudukan di Desa Sumber Datar Kec. Singingi Kab. Kuantan Singingi. Tujuan penelitian ini adalah untuk mengetahui factor-faktor apakah yang mempengaruhi perilaku anggota koperasi dalam mengambil keputusan untuk membeli barang di KUD Karya Agung. Sedangkan manfaat yang dapat penulis berikan kepada koperasi adalah sebagai bahan masukan atau informasi bagi manajemen KUD Karya Agung mengenai perilaku anggota koperasi dalam mengambil keputusan untuk membeli barang yang ditawarkan oleh koperasi. Berdasarkan pada perumusan masalah dan tujuan penelitian, penulis mengajukan hipotesis yaitu diduga perilaku anggota koperasi dalam mengambil keputusan untuk membeli barang di KUD Karya Agung di pengaruhi oleh faktor kebudayaan, kelas sosial, sikap dan psikologi. Dari penelitian yang penulis lakukan dapat diambil suatu kesempatan bahwa faktorfaktor yang mempengaruhi perilaku anggota koperasi dalam mengambil keputusan untuk membeli barang di KUD Karya Agung adalah factor lingkunagan sosial, sikap dan psikologi.

Kata Kunci: Perilaku Anggota, Pengambilan Keputusan, Kebudayaan, Kelas Sosial, Sikap dan Psikologi

\section{PENDAHULUAN}

Koperasi adalah sebagai suatu badan usaha yang tujuan utamanya untuk memajukan kepentingan ekonomi dari setiap anggotanya yang secara nyata dilihat dari sisi ilmu ekonomi adalah suatu badan usaha yang dinilai sebagai usaha yang sangat efisien dalam meningkatkan ekonomi masyarakat umumnya dan anggota khususnya. Dengan semakin pesatnya perkembangan dunia usaha saat ini, koperasi dituntut untuk mampu bersaing dengan perusahaan lainnya agar dapat mempertahankan kedudukan kompetitifnya dalam pasar. Hal ini dapat tercapai bila koperasi mampu mengendalikan aspek-aspek seperti 
modal, produksi, teknologi, dan tidak kala pentingnya adalah pemasaran.

Sejak pelita I sampai sekarang, pemerintah dan swasta telah menunjukan peranannya yang berarti dalam menunjang keberhasilan pembangunan. Namun koperasi bukanlah tidak ada peranannya sama sekali, tetapi peranan yang dimainkan oleh koperasi itu dalam menunjang pembangunan yang belum dapat dikatakan berarti, karena koperasi sendiri sibuk dalam membenah diri untuk memenuhi tugas dan kewajiban yang diberikan kepadanya. Disatu pihak koperasi dituntut untuk dapat memajukan diri seperti swasta dan dilain pihak sekaligus harus mensejahterakan anggota.

Koperasi tidak akan mampu berkembang dengan baik tanpa didukung oleh sikap positif para anggotanya. Sikap tersebut dibuktikan dengan perilaku anggota, semakin banyak anggotanya semakin beraneka ragam jenis perilaku anggota dalam membeli barang kebutuhannya. Perilaku positif dari anggota akan memberikan kontribusi terhadap peningkatan usaha misalnya, meningkatkan pembeliannya dan aktif menghadiri rapat. Anggota koperasi dituntut kesetiannya berlangganan koperasi tempat dia bergabung dimaksud dengan berlangganan disini yaitu jika koperasi konsumsi para anggotanya aktif membeli dikoperasinya. Jadi anggota tidak hanya sekedar jadi anggota tetapi berlangganan secara aktif pada koperasi, sehingga dengan demikian usaha koperasi akan dapat berkembang.

Koperasi unit desa Karya Agung ini berlokasi di Desa Sumber Datar Kec. Singingi. Koperasi ini bergerak dalam beberapa unit usaha yang terdiri dari unit simpan pinjam, toserba, tandan buah segar, kantin dan armada serta jasa lainnya. Dalam bidang toserba boleh dikatakan tidak menemukan hambatan atau kendala, hal ini disebabkan karena tersedianya kebutuhan sehari-hari yang cukup, dengan demikian koperasi telah mampu menyediakan kebutuhan anggota dalam jumlah yang relative besar. Hal ini harus diikuti dengan kegiatan pemasaran yang intensif, sehingga apa yang menjadi tujuan koperasi dapat tercapai yaitu memperoleh laba dari hasil penjualan serta mensejahterakan anggota khususnya.
Dalam rangka pengembangan usaha pemasaran perilaku konsumen sangat penting, karena manajer akan mempunyai pandangan yang lebih luas dan mengetahui peluang baru yang berasal dari belum terpenuhinya kebutuhan konsumen. Untuk keperluan tersebut maka tahap pertama yang harus dilakukan adalah variabel-variabel apa saja yang mempengaruhi perilaku konsumen, dalam hal ini yang harus diperhatikan adalah factor-faktor apa saja yang dapat menstimuli konsumen untuk membeli suatu barang, biasanya factorfaktor yang dapat menstimuli konsumen selalu berkaitan dengan diri konsumen sendiri, dan bagaimana upaya menjual mempengaruhi konsumen. Hal tersebut tidak jauh berbeda dengan koperasi unit desa (KUD) Karya Agung Sumber Datar yang berada di Kecamatan Singingi Kabupaten Kuantan Singingi. Yang mengalami fluktuatif SHU selama dua tahun.

\section{TINJAUAN PUSTAKA}

\subsection{Pengertian Koperasi}

Salah satu bentuk kerja sama dalam lapangan perekonomian adalah koperasi. Kerja sama dalam koperasi ini dilaksanakan berdasarkan prinsip saling membutuhkan dan kesamaan kebutuhan sehari-hari, baik yang terkait dengan keperluan pribadi maupun perusahaan. Untuk mencapai tujuan itu, suatu kerja sama yang berlangsung secara terus menerus sangat diperlukan (Anoeraga \& Sudantoko, 2002).

Dasar hukum keberadaan koperasi di Indonesia adalah UUD 1945 Pasal 33 ayat (1) yang menyatakan bahwa "Perekonomian disusun sebagai usaha bersama berdasarkan atas azaz kekeluargaan". Sedangkan landasan operasional koperasi di Indonesia adalah UU No. 25 Tahun 1992 Tentang Perkoperasian. Dalam pasal 1 ayat (1) yang berbunyi "Koperasi adalah badan usaha yang beranggotakan orang-orang atau badan hukum koperasi dengan melaksanakan kegiatan berdasarkan prinsip koperasi sekaligus sebagai gerakan ekonomi rakyat yang berdasarkan atas azas kekeluargaan' (Undang-undang Perkoperasian No.25 Tahun 1992)

\subsection{Pengertian Perilaku Konsumen}


Perilaku orang dalam suatu organisasi atau kelompok tidak sama. Semakin besar suatu organisasi semakin banyak anggotanya dan semakin beragam jenis perilakunya. Dalam koperasi anggota adalah sebagai pelanggan dan sekaligus sebagai konsumen. Pelanggan adalah semua orang yang menuntut perusahaan untuk memenuhi standar kualitas tertentu dan karena itu akan memberikan pengaruh pada performance perusahaan (Gasperz, 1997) Berbicara tentang konsumen berarti juga membicarakan perilaku manusia. Perilaku konsumen dapat diartikan kegiatan individuindividu yang secara langsung terlihat dalam mendapatkan dan menggunakan barang dan jasa termasuk di dalamnya proses pengambilan keputusan pada persiapan dan penentuan kegiatan-kegiatan tersebut (Mangkunegara, 1998)

\subsection{Model Perilaku Konsumen}

Tujuan kegiatan pemasaran adalah mempengaruhi pembeli untuk bersedia membeli barang yang disediakan oleh koperasi pada saat mereka membutuhan. Dalam hali ini pengurus hendaknya dapat memahami, "Mengapa" dan "Bagaimana" tingkah laku konsumen sehingga koperasi dapat mengembangkan, menentukan harga, mempromosikan dan mendistribusikan barangbarangnya secara lebih baik. Dengan demikian pengurus akan mengetahui kesempatan baru yang belum terpenuhi kebutuhannya dan mengidentifikasikannya untuk mengadakan segmentasi pasar.

Untuk mengetahui dan memahami perilaku konsumen dalam melakukan pembelian akan diuraikan secara singkat faktor - faktor yang mempengaruhi perilaku konsumen, menganalisa perilaku konsumen adalah suatu yang sangat komplek terutama banyaknya variable yang mempengaruhi kecendrungannya untuk saling berinteraksi.

Perilaku pembelian konsumen akan dipengaruhi oleh factor-faktor budaya, sosial, pribadi dan psikologis. Factor-faktor budaya mempengaruhi perilaku konsumen.

\subsection{Hipotesis}

Berdasarkan pada perumusan masalah dan tujuan penelitian, penulis mengajukan hipotesis sebagai berikut : "Diduga perilaku anggota koperasi dalam mengambil keputusan untuk membeli barang dagang pada KUD Karya Agung yang berkedudukan di Desa Sumber Datar Kec. Singingi Kab. Kuantan Singingi dipengaruhi oleh faktor kebudayaan, kelas sosial, sikap dan psikologis".

\subsection{Variabel Penelitian}

Dalam upaya pemecahan masalah ada beberapa variable penelitian yang akan diteliti, yang ada hubungannya dengan permasalahan yaitu :
a) Kebudayaan
b) Lingkungan Sosial
c) Sikap
d) Psikologi

\section{METODE PENELITIAN}

\subsection{Jenis dan Sumber Data}

Adapun jenis dan sumber data yang dikumpulkan dalam penelitian adalah

a) Data Primer yaitu data yang diperoleh dilapangan melalui daftar pertanyaan dengan responden terpilih yang ada di KUD Karya Agung yaitu data yang berupa informasi tentang factor-faktor yang mempengaruhi perilaku anggota dalam pembelian barang.

b) Data Sekunder yaitu data yang penulis peroleh dari sumber yang ada kaitannya dengan penelitian ini berupa data yang telah jadi.

\subsection{Teknik Pengumpulan Data}

Untuk memeproleh data yang diperlukan dalam penelitian ini, maka penulis menggunakan teknik pengumpulan data yaitu :

a) Interview yaitu merupakan proses percakapan secara langsung dengan pengurus dan responden yang terstruktur kepada anggota pembeli barang dan jasa yang kemudian dijadikan responden dalam penelitian ini.

b) Questioner yaitu dengan memberikan pertanyaan kepada seluruh responden yang terpilih, daftar pertanyaan yang diajukan telah disiapkan beberapa alternatif jawaban yang telah diarahkan dan 
disesuaikan dengan pokok masalah dan tujuan penelitian.

\subsection{Populasi dan Sampel}

Populasi adalah wilayah generalisasi yang terdiri dari obyek atau subyek yang mempunyai kuantitas dan karakteristik tertentu yang ditetapkan oleh penelitian untuk dipelajari dan kemudian ditarik kesimpulan (Istijanto, 2006)

Populasi dalam penelitian ini adalah seluruh anggota KUD Karya Agung sebanyak 550 orang, karena populasi cukup banyak penulis mengambil sampel untuk mewakili populasi. Hal tersebut sesuai dengan pendapat (Sugiyono, 1999 :72) yang mengatakan dalam penelitian tidaklah selalu perlu untuk meneliti semua individu dalam populasi.

Dalam penentuan pengambilan sampel seperti dikemukakan oleh (Singarimbun \& Efendi, 2001) dalam bukunya metode penelitian survey yang mengatakan beberapa peneliti menyatakan bahwa besarnya sampel tidak boleh kurang dari 10\%. (Winarno, 1997) dalam buku metodelogi penelitian karangan Cholid dan Abu Achmadi memberikan pedoman "Apabila populasi cukup homogen (serba sama) terhadap populasi dapat dipergunakan sampel 10\%-20\%. Berdasarkan pendapat tersebut maka penulis mengambil sebanyak 55 orang dari seluruh populasi.

Jadi populasi dalam penelitian ini adalah seluruh anggota KUD Karya Agung sebanyak 550 orang dan sampel $10 \%$ dari populasi sebanyak 55 orang dengan menggunakan Metode Purposive Sampling yaitu pengambilan sampel berdasarkan pertimbangan penulis dengan secara kebetulan dan acak dari setiap anggota koperasi (Husein, 2003).

\subsection{Analisis Data}

Dalam menganalisis data yang berhasil dikumpulkan penulis menggunakan metode analisis deskriptif yaitu metode yang bersifat menjelaskan atau menguraikan data dan informasi yang diperoleh dilapangan kemudian dihubungkan dengan landasan teori-teori yang relevan dan selanjutnya disimpulkan.

\section{HASIL PENELITIAN DAN PEMBAHASAN}

Dalam bagian ini akan diuraikan hasil penelitian dan pembahasan mengenai faktorfaktor yang mempengaruhi perilaku anggota koperasi dalam mengambil keputusan untuk membeli barang pada KUD Karya Agung Kec. Singingi Kab. Kuantan Singingi. Dengan menggunakan analisis deskriptif, maka data yang didapat ini akan diolah sehingga dapat menjawab kebenaran hipotesis. Data yang ada diperoleh dengan cara memberikan daftar pertanyaan kepada anggota koperasi yang telah terpilih sebagai responden yaitu sebanyak 55 orang. Selanjutnya data yang diperoleh tersebut ditabulasi untuk dianalisis secara deskriptif.

Adapun variabel yang diduga atau

dianggap mempengaruhi perilaku anggota koperasi dalam mengambil keputusan untuk membeli barang di KUD Karya Agung yang meliputi faktor kebudayaan, sikap, kelas sosial dan psikologis. Adapun hasil penelitian dan pembahasan terhadap analisis perilaku anggota koperasi dalam mengambil keputusan untuk membeli barang pada KUD Karya Agung adalah sebagai berikut :

\subsection{Analisis Faktor Kebudayaan}

Kebudayaan merupakan simbol yang diciptakan oleh manusia diturunkan dari generasi ke generasi sebagai penentu atau pengatur tingkah laku manusia dalam masyarakat, kebudayaan ini juga salah satu faktor yang bisa memodifikasi perilaku seseorang. Variabel ini menggambarkan aspek kehidupan manusia, baik pengetahuan, keyakinan, adat istiadat serta perkembangan zaman dan budaya lain serta kebiasaan yang diddapat oleh manusia sebagai anggota masyarakat, dalam kenyataannya memang banyak perilaku manusia yang ditentukan oleh kebudayaan dan pengaruhnya akan selalu berubah setiap waktu sesuai dengan kemajuan atau perkembangan zaman dari masyarakat tersebut. Penjelasan lebih lanjut dapat dilihat pada tabel berikut ini:

Tabel 1.Tanggapan responden tentang pengaruh perubahan, perkembangan dan 
kemajuan budaya dalam membeli barang atau berbelanja di KUD Karya Agung

\begin{tabular}{|c|l|c|c|}
\hline No & Tanggapan Responden & $\begin{array}{c}\text { Frekue } \\
\text { nsi }\end{array}$ & $\begin{array}{c}\text { Perse } \\
\text { ntase } \\
(\%)\end{array}$ \\
\hline 1 & Sangat mempengaruhi & 2 & 3,64 \\
2 & Mempengaruhi & 4 & 7,27 \\
3 & Biasa-biasa saja & 10 & 18,18 \\
4 & Tidak mempengaruhi & 24 & 43,64 \\
5 & Sangat tidak & 15 & 27,27 \\
& mempengaruhi & & \\
\hline \multicolumn{2}{|l|}{ Jumlah } & 55 & 100 \\
\hline
\end{tabular}

Sumber : Data Olahan

Dari tabel 1 di atas diketahui bahwa tanggapan responden mengenai pengaruh perubahan, perkembangan dan kemajuan budaya terhadap perilaku pengambilan keputusan untuk membeli barang atau berbelanja di KUD Karya Agung dapat menunjukkan bahwa reponden yang menjawab sangat mempengaruhi sebanyak 2 orang atau $3,64 \%$, mempengaruhi sebanyak 4 orang atau $7,27 \%$, biasa-biasa saja sebanyak 10 orang atau $18,18 \%$, tidak mempengaruhi sebanyak 24 orang atau $43,64 \%$ dan sangat tidak mempengaruhi sebanyak 15 orang atau $27,27 \%$.

Dengan demikian dapat disimpulkan bahwa pengaruh tentang perubahan, perkembangan dan kemajuan budaya tidak mempengaruhi responden dala mengambil keputusan dalam membeli barang pada KUD Karya Agung. Karena para anggota KUD Karya Agung memiliki berbagai suku dan mereka cenderung ke budaya asli mereka masing-masing.

Selanjutnya untuk mengetahui pengaruh adat istiadat dari suku dan keturunan responden terhadap keputusan membeli barang pada KUD Karya Agung dapat dilihat pada tabel berikut :

Tabel 2.Tanggapan responden tentang pengaruh adat istiadat dari suku dan keturunan dalam membeli barang atau berbelanja di

\begin{tabular}{|c|l|c|c|}
\multicolumn{5}{|c}{ KUD Karya Agung } \\
\hline No & $\begin{array}{c}\text { Tanggapan } \\
\text { Responden }\end{array}$ & $\begin{array}{c}\text { Frekue } \\
\text { nsi }\end{array}$ & $\begin{array}{c}\text { Persent } \\
\text { ase }(\%)\end{array}$ \\
\hline 1 & Sangat & 6 & 10,91 \\
2 & mempengaruhi & 9 & 16,36 \\
\hline
\end{tabular}

\begin{tabular}{|c|l|c|c|}
\hline 3 & Mempengaruhi & 16 & 29,09 \\
4 & Bias-biasa saja & 19 & 34,55 \\
5 & Tidak & 5 & 9,09 \\
& mempengaruhi & & \\
& Sangat tidak & & \\
& mempengaruhi & & \\
\hline \multicolumn{2}{|l}{ Jumlah } & 55 & 100 \\
\hline
\end{tabular}

Sumber : Data Olahan

Dari tabel 2 diatas diketahui bahwa tanggapan responden mengenai pengaruh adat istiadat dari suku dan keturunan terhadap perilaku pengambilan keputusan untuk membeli barang atau berbelanja di KUD Karya Agung dapat menunjukkan bahwa responden yang menjawab sangat mempengaruhi sebanyak 6 orang atau $10,91 \%$, mempengaruhi sebanyak 9 orang atau $16,36 \%$, biasa-biasa saja sebanyak 16 orang atau $29,09 \%$, tidak mempengaruhi sebanyak 19 orang atau $34,55 \%$ dan sangat tidak mempengaruhi sebanyak 5 orang atau $9,09 \%$.

Dari tanggapan responden tersebut sebagian besar responden menjawab adat istiadat dari susku dan keturunan para anggota KUD Karya Agung juga tidak mempengaruhi responden dalam membeli barang atau berbelanja. Ini merupakan contoh bagi calon anggota lainnya. Dikarenakan para anggota KUD Karya Agung terdiri dari berbagai macam suku dan keturunan, karena merupakan daerah transmigrasi, tetapi mereka tetap selalu kompak dalam membangun daerahnya.

Sedangkan untuk mengetahui pengaruh dari perkembangan zaman dan budaya responden terhadap keputusan membeli barang atau berbelanja pada KUD Karya Agung dapat di lihat pada tabel di bawah ini :

Tabel 3. Tanggapan responden dari perkembangan zaman dan budaya terhadap

keputusan dalam membeli barang atau

berbelanja di KUD Karya Agung
\begin{tabular}{|c|l|c|c|}
\hline No & \multicolumn{1}{|c|}{$\begin{array}{c}\text { Tanggapan } \\
\text { Responden }\end{array}$} & $\begin{array}{c}\text { Frekue } \\
\text { nsi }\end{array}$ & $\begin{array}{c}\text { Persent } \\
\text { ase }(\%)\end{array}$ \\
\hline 1 & Sangat setuju & 5 & 9,09 \\
2 & Setuju & 9 & 16,36 \\
3 & Biasa-biasa saja & 24 & 43,64 \\
4 & Tidak setuju & 13 & 23,64 \\
5 & Sangat tidak setuju & 4 & 7,27 \\
\hline & & 55 & 100 \\
\hline
\end{tabular}


Sumber : Data Olahan

Dari tabel 3 diatas diketahui bahwa tanggapan responden mengenai perkembangan zaman dan budaya terhadap perilaku pengambilan keputusan untuk membeli barang atau berbelanja di KUD Karya Agung dapat menunjukkan bahwa responden yang menjawab sangat setuju sebanyak 5 orang atau $9.09 \%$, setuju sebanyak 9 orang atau $16,36 \%$, biasa-biasa saja sebanyak 24 orang atau $43,64 \%$, tidak setuju sebanyak 13 orang atau $23,64 \%$ dan sangat tidak setuju sebanyak 4 orang atau $7,27 \%$.

Dengan demikian dapat disimpulkan tanggapan responden tersebut sebagian besar menjawab biasa-biasa saja, dikarenakan responden tidak terlalu memperhatikan perkembangan zaman dan budaya yang ada pada saat ini. Dan seterusnya untuk mengetahui tanggapan responden tentang agama yang diyakini responden terhadap keputusan membeli barang di KUD Karya Agung dapat dilihat pada tabel berikut ini :

Tabel 4. Tanggapan responden tentang agama yang diyakini responden terhadap keputusan dalam membeli barang atau berbelanja di

\begin{tabular}{|c|l|c|c|}
\multicolumn{5}{c}{ KUD Karya Agung } \\
\hline No & Tanggapan Responden & $\begin{array}{c}\text { Freku } \\
\text { ensi }\end{array}$ & $\begin{array}{c}\text { Persent } \\
\text { ase }(\%)\end{array}$ \\
\hline 1 & Sangat mempengaruhi & 4 & 7,27 \\
2 & Mempengaruhi & 6 & 10,91 \\
3 & Bias-biasa saja & 13 & 23,64 \\
4 & Tidak mempengaruhi & 15 & 27,27 \\
5 & Sangat tidak & 17 & 30,91 \\
& mempengaruhi & & \\
\hline \multicolumn{4}{|l|}{ Jumlah } \\
\hline
\end{tabular}

Sumber : Olahan Data

Dari tabel 4 diatas diketahui bahwa tanggapan responden tentang agama yang diyakini terhadap perilaku pengambilan keputusan untuk membeli barang atau berbelanja di KUD Karya Agung dapat menunjukkan bahwa responden yang menjawab sangat mempengaruhi sebanyak 4 orang atau $7,27 \%$, mempengaruhi sebanyak 6 orang atau $10,91 \%$, biasa-biasa saja sebanyak 13 orang atau $23,64 \%$, tidak mempengaruhi sebanyak 15 orang atau $27,27 \%$ dan sangat tidak mempengaruhi sebanyak 17 orang atau $30,91 \%$

Dengan demikian dapat disimpulkan bahwa tanggapan responden tentang agama yang diyakini terhadap keputusan membeli barang pada KUD Karya Agung sangat tidak mempengaruhi responden karena barangbarang yang ada dikoperasi pada umumnya barang yang diinginkan oleh permintaan para anggota terlebih dahulu.

\subsection{Analisis Faktor Lingkungan Sosial}

Variabel kelas sosial merupakan salah satu faktor untuk membentuk perilaku seseorang. Kelompok acuan sesseorang yang semua kelompok mempunyai pengaruh langsung ataupun tidak langsung terhadap pendirian atau perilaku seseorang. Kelas sosial adalah bagian yang relatif homogen dalam suatu masyarakat yang tersusun secara hirarkis dan anggotanya memiliki tata nilai, minat dan perilaku yang mirip.

Kelas sosial ini memiliki beberapa karakteristik, orang mempunyai posisi yanng lebih tinggi atau rendah menurut kelas sosial, kelas sosial seseorang digambarkan dengan acuan seperti keluarga, anggota keluarga, pihak lain serta teman bergaul. Dengan penjelasan lebih lanjut dapat di lihat pada tabel di sebelah ini :

Tabel 5. Tannggapan responden tentang pengaruh jumlah anggota keluarga dalam membeli barang atau berbelanja di KUD

\begin{tabular}{|c|l|c|c|}
\hline \multicolumn{5}{|c}{ Karya Agung } \\
\hline No & \multicolumn{1}{|c|}{$\begin{array}{c}\text { Tanggapan } \\
\text { Responden }\end{array}$} & $\begin{array}{c}\text { Frekuens } \\
\text { i }\end{array}$ & $\begin{array}{c}\text { Persentas } \\
\text { e (\%) }\end{array}$ \\
\hline 1 & Sangat & 9 & 16,36 \\
2 & mempengaruhi & 12 & 21,82 \\
3 & Mempengaruhi & 24 & 43,64 \\
4 & Bias-biasa saja & 6 & 10,91 \\
5 & Tidak & 4 & 7,27 \\
& mempengaruhi & & \\
& Sangat tidak & & \\
\hline \multicolumn{4}{|l|}{ Jumpengaruhi } \\
\end{tabular}

Sumber : Data Olahan 
Dari table 5 diatas diketahui bahwa tanggapan responden tentang pengaruh jumlah anggota keluarga terhadap perilaku pengambilan keputusan untuk membeli barang atau berbelanja di KUD Karya Agung dapat menunjukkan bahwa responden yang menjawab sangat mempengaruhi sebanyak 9 orang atau 16,36\%, mempengaruhi sebanyak 12 orang atau $21,82 \%$, biasa-biasa saja sebanyak 24 orang atau $43,64 \%$, tidak mempengaruhi sebanyak 6 orang atau $10,91 \%$ dan sangat tidak mempengaruhi sebanyak 4 orang atau $7,27 \%$.

Dengan demikian dapat disimpulkan bahwa pengaruh tentang jumlah anggota keluarga biasa-biasa saja bagi responden dalam mengambil keputusan untuk membeli barang pada KUD Karya Agung. Karena dalam membeli barang responden memiliki kebutuhan pribadi yang berbeda sesuai dengan selera dan keinginan masing-masing walaupun berada dalam satuu keluarga.

Selanjutnya untuk mengetahui tanggapan dari keluarga responden untuk memutuskan membeli barang atau berbelanja pada KUD Karya Agung dapat dilihat pada tabel berikut :

Tabel 6. Tanggapan dari keluarga responden ketika memutuskan untuk membeli barang atau berbelanja di KUD Karya Agung

\begin{tabular}{|c|l|c|c|}
\hline No & Tanggapan Responden & $\begin{array}{c}\text { Freku } \\
\text { ensi }\end{array}$ & $\begin{array}{c}\text { Persent } \\
\text { ase (\%) }\end{array}$ \\
\hline 1 & Sangat setuju & 8 & 14,55 \\
2 & Setuju & 27 & 49,09 \\
3 & Biasa-biasa saja & 10 & 18,18 \\
4 & Tidak setuju & 7 & 12,73 \\
5 & Sangat tidak setuju & 3 & 5,45 \\
\hline \multicolumn{2}{|c|}{ Jumlah } & 55 & 100 \\
\hline
\end{tabular}

Sumber : Olahan Data

Dari tabel 6 diatas diketahui bahwa tanggapan dari keluarga responden untuk memutuskan perilaku pengambilan keputusan untuk membeli barang atau berbelanja di KUD Karya Agung dapat menunjukkan bahwa responden yang menjawab sangat setuju sebanyak 8 orang atau $14,55 \%$, setuju sebanyak 27 orang atau $49,09 \%$, biasa-biasa saja sebanyak 10 orang atau $18,18 \%$, tidak setuju sebanyak 7 orang atau $12,73 \%$, dan sangat tidak setuju sebanyak 3 orang atau $5,45 \%$.

Dari tanggapan responden tersebut sebagian besar responden menjaawab setuju dengan keputusan keluarga dalam membeli barang atau berbelanja pada KUD Karya Agung. Dikarenakan responden sebagai anggota koperasi maka keluarga mendukung responden untuk berbelanja pada KUD Karya Agung. Karena baranng-barang yang ada di koperasi pada umumnya sesuai dengan kebutuhan anggota, dan juga demi meningkatkan omzet dari koperasi tersebut.

Sedangkan untuk mengetahui pengaruh responden dari pihak-pihak lain terhadap keputusan membeli barag atau berbelanja pada KUD Karya Agung dapat di lihat pada tabel di bawah ini :

Tabel 7. Tanggapan responden tentang pengaruh pihak-pihak lain terhadap pengambilan keputusan dalam membeli barang atau berbelanja di KUD Karya Agung

\begin{tabular}{|c|l|c|c|}
\hline No & Tanggapan Responden & $\begin{array}{c}\text { Frekue } \\
\text { nsi }\end{array}$ & $\begin{array}{c}\text { Perse } \\
\text { ntase } \\
(\%)\end{array}$ \\
\hline 1 & Sangat mempengaruhi & 2 & 3,63 \\
2 & Mempengaruhi & 7 & 12,73 \\
3 & Bias-biasa saja & 11 & 20 \\
4 & Tidak mempengaruhi & 22 & 40 \\
5 & Sangat tidak & 13 & 23,64 \\
& mempengaruhi & 55 & 100 \\
\hline \multicolumn{2}{|l|}{ Jumlah } & & \\
\hline
\end{tabular}

Sumber : Data Olahan

Dari tabel 7 diatas diketahui bahwa tanggapan responden tentang pengaruh pihakpihak lain terhadap perilaku pengambilan keputusan untuk membeli barang atau berbelanja di KUD Karya Agung dapat menunjukkan bahwa responden yang menjawab sangat mempengaruhi sebanyak 2 orang atau $3,63 \%$, mempengaruhi sebanyak 7 orang atau $12,73 \%$, biasa-biasa saja sebanyak 11 orang atau $20 \%$, tidak mempengaruhi sebnyaka 22 orang atau $40 \%$ dan sangat tidak mempengaruhi sebanyak 13 orang atau $23,64 \%$.

Dengan demikian dapat disimpulkan tanggapan responden tersebut sebagian besar 
menjawab tidak mempengaruhi, karena responden tidak terlalu memperhatikan pihakpihak lain serta percaya diri dengan adanya barang-barang yang telah di koperasi pada saat ini.

Dan seterusnya untuk mengetahui tanggapan responden mengenai teman bergaul, tetangga dan rekan kerja terhadap keputusan membeli barang di KUD Karya Agung dapat di lihat pada tabel berikut ini:

Tabel 8. Tanggapan responden tentang pengaruh teman bergaul, tetangga dan rekan kerja terhadap pengambilan keputusan dalam membeli barang atau berbelanja di KUD

\begin{tabular}{|c|c|c|c|}
\hline \multicolumn{4}{|c|}{ Karya Agung } \\
\hline No & $\begin{array}{l}\text { Tanggapan } \\
\text { Responden }\end{array}$ & $\begin{array}{c}\text { Frekue } \\
\text { nsi }\end{array}$ & $\begin{array}{l}\text { Persent } \\
\text { ase }(\%)\end{array}$ \\
\hline 1 & Sangat & 9 & 16,63 \\
\hline 2 & mempengaruhi & 23 & 41,82 \\
\hline 3 & Mempengaruhi & 22 & 20 \\
\hline 4 & Bias-biasa saja & 10 & 18,18 \\
\hline 5 & $\begin{array}{l}\text { Tidak } \\
\text { mempengaruhi } \\
\text { Sangat tidak } \\
\text { mempengaruhi }\end{array}$ & 2 & 3,64 \\
\hline & Jumlah & 55 & 100 \\
\hline
\end{tabular}

Sumber : Data Olahan

Dari tabel 8 diatas diketahui bahwa tanggapan responden tentang pengaruh teman bergaul, tetangga dan rekan kerja terhadap perilaku pengambilan keputusan untuk membeli barang atau berbelanja di KUD Karya Agung dapat menunjukkan bahwa responden yang menjawab sangat mempengaruhi sebanyak 9 orang atau 16,63\%, mempengaruhi sebanyak 23 orang atau $41,83 \%$, biasa-biasa saja sebanyak 22 orang atau $20 \%$, tidak memepengaruhi sebanyak 10 orang atau $18,18 \%$ dan sangat tidak mempengaruhi sebanyak 2 orang atau 3,64\%.

Dengan demikian dapat disimpulkan bahwa tanggapan responden tentang pengaruh teman bergaul, tetangga dan rekan kerja tterhadap keputusan membeli barang pada KUD Karya Agung mempengaruhi responden, karena dalam kehidupan selalu berhubungan dan berkomunikasi sehingga dapat menimbulkan dan membawa responden untuk membeli barang-barang yang ada dikoperasi.

\subsection{Analisis Faktor Sikap}

Perilaku seseorang juga dipengaruhi oleh variabel sikap seseorang dari semua perbuatannya di masa lalu atau dapat juga dipelajari melalui proses belajar. Pengetahuan seseorang dihasilkan melalui suatu proses yang saling mempengaruhi dari dorongan inisiatif, pengalaman san perasaan. Menurut sikap seseorang dapat digambarkan dengan acuan seringnya responden mengunjungi koperasi, inisiatif dan perasaan untuk keputusan berbelanja.

Untuk lebih jelasnya hasil penelitian terhadap responden mengenai kunjungan atau berbelanja setiap bulan pada KUD Karya Agung dapat di lihat pada tabel berikut ini:

Tabel 9.Tanggapan responden mengenai kunjungan atau berbelanja di KUD Karya Agung dalam sebulan

\begin{tabular}{|c|l|c|c|}
\hline No & \multicolumn{1}{|c|}{$\begin{array}{c}\text { Tanggapan } \\
\text { Responden }\end{array}$} & $\begin{array}{c}\text { Frekue } \\
\text { nsi }\end{array}$ & $\begin{array}{c}\text { Persentase } \\
(\%)\end{array}$ \\
\hline 1 & 1 kali & 5 & 9,09 \\
2 & 2 kali & 7 & 12,73 \\
3 & 3 kali & 8 & 14,54 \\
4 & 4 kali & 11 & 20 \\
5 & Lebih dari 4 & 24 & 43,64 \\
& kali & & \\
\hline \multicolumn{2}{|l|}{ Jumlah } & 55 & 100 \\
\hline
\end{tabular}

Sumber : Olahan Data

Dari tabel 9 diatas diketahui bahwa tanggapan responden mengenai kunjungan atau berbelanja dalam waktu satu bulan terhadaap perilaku pengambilan keputusan untuk membeli barang atau berbelanja di KUD Karya Agung dapat menunjukkan bahwa responden yang menjawab 1 kali sebanyak 5 orang atau $9,09 \%, 2$ kali sebanyak 7 orang atau $12,73 \%, 3$ kali sebanyak 8 orang atau 14,54\%, 4 kali sebanyak 11 orang atau $20 \%$ dan lebih dari 4 kali sebanyak 24 orang atau 43,64\%.

Dengan demikian dapat disimpulkan bahwa responden sering berbelanja di koperasi karena letak koperasi strategis yang berada di pusat keramaian masyarakat dan juga terletak lebih jauh dari pasar, dan juga didukung oleh kelengkapan barang di koperasi.

Selanjutnya untuk mengetahui tanggapan responden mengenai inisiatif atau 
ajakan siapakah untuk memutuskan membeli barang atau berbelanja pada KUD Karya Agung dapat dilihat pada tabbel berikut :

Tabel 10. Tanggapan responden mengenai inisiatif atau ajakan siapakah untuk pengambilan keputusan dalam pembelian barag atau berbelanja di KUD Karya Agung

\begin{tabular}{|c|c|c|c|}
\hline No & $\begin{array}{l}\text { Tanggapan } \\
\text { Responden } \\
\end{array}$ & $\begin{array}{c}\text { Frekue } \\
\text { nsi }\end{array}$ & $\begin{array}{l}\text { Persentas } \\
\text { e }(\%)\end{array}$ \\
\hline 1 & Pribadi & 20 & 36,36 \\
\hline 2 & Keluarga & 24 & 43,64 \\
\hline 3 & Teman & 6 & 10,91 \\
\hline 4 & Rekan kerja & 5 & 9,09 \\
\hline 5 & Lain-lain & 0 & 0 \\
\hline & Jumlah & 55 & 100 \\
\hline
\end{tabular}

Sumber : Data Olahan

Dari tabel 10 diatas diketahui bahwa tanggapan responden mengenai inisiatif atau ajakan dari siapakah untuk mengunjungi atau berbelanja terhadap perilaku keputusan untuk membeli barang di KUD Karya Agung dapat meenunjukkan bahwa pribadi responden yang menjawab sebanyak 20 orang atau $36,36 \%$, keluarga sebanyak 25 orang atau $43,64 \%$, teman sebanyak 6 orang atau $10,91 \%$, rekan kerja sebanyak 5 orang atau $9,09 \%$ dan sangat tidak setuju sebanyak 0 orang atau $0 \%$.

Dari tanggapan responden tersebut sebagian besar responden menjawab mengenai inisiatif atau ajakan siapakah keputusan salam membeli barang atau berbelanja pada KUD Karya Agung adalah dari dorongan keluarga.. dikarenakan kebanyakan responden memiliki kebutuhan barang yang sama di dalam keluarga sehingga sangat mendorong responden dalam berbelanja pada KUD Karya Agung setelah kita berbelanja maka dapat di lihat pada tabel di bawah ini :

Tabel 11. Tanggapan responden mengenai keinginan mengajak orang lain setelah kita berbelanja terhadap pengambilan keputusan dalam membeli barang atau berbelanja di

\begin{tabular}{|c|l|c|c|}
\multicolumn{4}{c|}{ KUD Karya Agung } \\
\hline No & \multicolumn{1}{|c|}{$\begin{array}{c}\text { Tanggapan } \\
\text { Responden }\end{array}$} & $\begin{array}{c}\text { Frekue } \\
\text { nsi }\end{array}$ & $\begin{array}{c}\text { Persentas } \\
\text { e }(\%)\end{array}$ \\
\hline 1 & Sangat ingin & 18 & 32,73 \\
2 & Ingin & 26 & 47,27 \\
3 & Biasa-biasa saja & 9 & 16,36 \\
\hline
\end{tabular}

\begin{tabular}{|c|l|c|c|}
\hline 4 & $\begin{array}{l}\text { Tidak ingin } \\
\text { Sangat tidak } \\
\text { ingin }\end{array}$ & 0 & $\begin{array}{c}2 \\
0\end{array}$ \\
\hline \multicolumn{2}{|c|}{ Jumlah } & 55 & 100 \\
\hline
\end{tabular}

Sumber : Olahan Data

Dari tabel 11 diatas diketahui bahwa tanggapan responden mengenai keinginan mengajak orang lain setelah kita berbelanja terhadap perilaku pengambilan keputusan untuk membeli barang atau berbelanja di KUD Karya Agung dapat menunjukkan bahwa responden yang menjawab sangat ingin sebanyak 18 orang atau $32,73 \%$, ingin sebanyak 26 orang atau $47,27 \%$, biasa-biasa saja sebanyak 9 orang atau $16,36 \%$, tidak ingin sebanyak 2 orang atau 3,64 dan sangat tidak ingin sebanyak 0 orang atau $0 \%$.

Dengan demikian dapat disimpulkan bahwa tanggapan responden tersebut sebagian besar menjawab ingin mengajak orang lain ikut berbelanja di koperasi, karena responden secara tidak langsung ingin meningkatkan penjualan atau omzet koperasi sekaligus untuk menambah anggota koperasinya.

Dan seterusnya untuk mengetahui tanggapan responden mengenai rasa puas dalam berbelanja di KUD Karya Agung dapat di lihat pada tabel berikut ini:

Tabel 12. Tanggapan responden mengenai rasa puas setelah membeli barang atau berbelanja

\begin{tabular}{|c|c|c|c|}
\hline \multicolumn{4}{|c|}{ di KUD Karya Agung } \\
\hline No & $\begin{array}{l}\text { Tanggapan } \\
\text { Responden }\end{array}$ & $\begin{array}{c}\text { Frekue } \\
\text { nsi }\end{array}$ & $\begin{array}{c}\text { Persentas } \\
\text { e (\%) }\end{array}$ \\
\hline 1 & Sangat puas & 12 & 21,82 \\
\hline 2 & Puas & 23 & 41,82 \\
\hline 3 & Biasa-biasa saja & 13 & 23,64 \\
\hline 4 & Tidak puas & 5 & 9,09 \\
\hline 5 & Sangat tidak puas & 2 & 3,63 \\
\hline & Jumlah & 55 & 100 \\
\hline
\end{tabular}

Sumber : Data Olahan

Dari tabel 12 diatas diketahui bahwa tanggapan responden mengenai perasaan merasa puas setelah berbelanja terhadap perilaku pengambilan keputusan untuk membeli barang atau berbelanja di KUD Karya Agung dapat menunjukkan bahwa respon yang menjawab sangat puas sebanyak 12 orang atau 
$21,82 \%$, puas sebanyak 23 orang atau $41,82 \%$, biasa-biasa saja sebanyak 13 orang atau $23,64 \%$, tidak puas sebanyak 5 orang atau $9.09 \%$ dan sangat tidak puas sebanyak 2 orang atau $3,63 \%$.

Dengan demikian dapat disimpulkan bahwa tanggapan responden mengenai perasaan merasa puas setelah berbelanja terhadap keputusan membeli barang pada KUD Karya Agung, responden merasa puas, karena dalam berbelanja pada umumnya ketersediaan barang telah terpenuhi oleh koperasi menurut kebutuhan sehari-hari responden.

\subsection{Analisis Faktor Psikologis}

Dalam melakukan proses psikologis ini biasanya setiap orang selalu melakukan beberapa tahapan yang pada umumnya terdiri dari pengelolaan inforrmasi dimana informasi dikurangi, disimpan, dirinci, didapatkan kembali dan digunakan. Sebagian besar perilaku manusia adalah hasil belajar, pembelajaran dihasilkan perpaduan kerja, dorongan, rangsangan, petunjuk, tanggapan dan penguat. Perubahan sikap dan perilaku yaitu proses yang merupakan cerminan psikologi dari konsumen terhadap produk (barang) yang ingin dibelinya. Dari perubahan sikap dan perilaku ini dapat dibuat suatu pendesainan strategi promosi yang efektif.

Untuk lebih jelasnya guna melihat tanggapan responden mengenai proses psikologi ini maka dapat dilihat pada gambaran atau acuan pada tabel berikut ini :

Tabel 13. Tanggapan responden tentang pengaruh pelayanan terhadap pengambilan

keputusan untuk membeli barang atau berbelanja di KUD Karya Agung

\begin{tabular}{|c|l|c|c|}
\hline No & $\begin{array}{c}\text { Tanggapan } \\
\text { Responden }\end{array}$ & $\begin{array}{c}\text { Freku } \\
\text { ensi }\end{array}$ & $\begin{array}{c}\text { Persent } \\
\text { ase (\%) }\end{array}$ \\
\hline 1 & Sangat & 10 & 18,18 \\
2 & mempengaruhi & 19 & 34,54 \\
3 & Mempengaruhi & 17 & 30,91 \\
4 & Bias-biasa saja & 7 & 12,73 \\
5 & Tidak & 2 & 3,64 \\
& mempengaruhi & & \\
& Sangat tidak & & \\
& mempengaruhi & & \\
\hline
\end{tabular}

\begin{tabular}{|c|c|c|}
\hline Jumlah & 55 & 100 \\
\hline
\end{tabular}

Sumber : Olahan Data

Dari tabel 13 diatas diketahui bahwa tanggapan responden tentang pengaruh pelayanan terhadap perilaku pengambilan keputusan untuk membeli barang atau berbelanja di KUD Karya Agung dapat menunjukkan bahwa responden yang menjawab sangat puas sebanyak 10 orang atau $18,18 \%$, mempengaruhi sebanyak 19 orang atau 34,54\%, biasa-biasa saja sebanyak 17 orang atau $30,91 \%$, tidak mempengaruhi sebanyak 7 orang atau $12,73 \%$ dan sangat tidak mempengaruhi sebanyak 2 orang atau 3,64\%.

Dengan demikian dapat disimpulkan bahwa tanggapan responden tentang pengaruh pelayanan terhadap pengambilan keputusan membeli barag pada KUD Karya Agung mayoritas mempengaruhi responden, karena pihak koperasi tidak begitu sungguh-sungguh dalam melayani para anggota koperasi untuk berbelanja.

Selanjutnya untuk mengetahui tanggapan reponden mengenai pelayanan yang diberikan KUD Karya Agung apakah sudah memuaskan menurut penilaian tingkat kepuasan responden untuk memutuskan memberi barang atau berbelanja pada KUD Karya Agung dapat dilihat pada tabel berikut :

Tabel 14. Tanggapan responden mengenai pelayanan yang diberikan oleh KUD Karya Agung menurut tingkat kepuasan responden

\begin{tabular}{|c|l|c|c|}
\hline No & \multicolumn{1}{|c|}{$\begin{array}{c}\text { Tanggapan } \\
\text { Responden }\end{array}$} & $\begin{array}{c}\text { Frekue } \\
\text { nsi }\end{array}$ & $\begin{array}{c}\text { Perse } \\
\text { ntase } \\
(\%)\end{array}$ \\
\hline 1 & Sangat memuaskan & 4 & 10,27 \\
2 & Memuaskan & 6 & 10,91 \\
3 & Biasa-biasa saja & 20 & 36,36 \\
4 & Tidak memuaskan & 16 & 29,29 \\
5 & Sangat tidak & 9 & 16,36 \\
& memuaskan & 55 & 100 \\
\hline \multicolumn{2}{|l|}{} \\
\hline
\end{tabular}

Sumber : Data Olahan

Dari tabel 14 diatas diketahui bahwa tangggapan responden mengenai pelayanan yang diberikan oleh KUD Karya Agung terhadap perilaku pengambilan keputusan 
untuk membeli barang dapat menunjukkan bahwa reponden yang menjawab sangat memuaskan sebanyak 4 orang atau $10,27 \%$, memuaskan sebanyak 6 orang atau $10,91 \%$, biasa-biasa saja 20 orang atau $36,36 \%$, tidak memuaskan sebanyak 16 orang atau $29,29 \%$ dan sangat tidak memuaskan sebanyak 9 orang atau $16,36 \%$.

Dari tanggapan responden tersebut sebagian besar responden menjaab mengenai pelayanan yang diberikan oleh KUD Karya Agung terhadap pengabilan keputusan dalam membeli barang atau berbelanja adalah biasabiasa saja. Dikarenakkan koperasi tidak memiliki pelayanan yang berlebih terhadap para anggotanya karena keterbatasan karyawan serta sarana dan prasarana yang masih banyak kekurangan.

Sedangkan untuk mengetahui tanggapan responden mengenai kualitas atau kondisi serta mutu barang yang ada di KUD Karya Agung maka dapat di lihat pada tabel di bawah ini:

Tabel 15. Tanggapan responden dalam mempertimbangkan kualitas atau kondisi serta mutu barang terhadap pengambilan keputusan dalam membeli barang atau berbelanja di

\begin{tabular}{|c|l|c|c|}
\hline \multicolumn{5}{|c}{ KUD Karya Agung } \\
\hline No & $\begin{array}{l}\text { Tanggapan } \\
\text { Responden }\end{array}$ & $\begin{array}{c}\text { Frekue } \\
\text { nsi }\end{array}$ & $\begin{array}{c}\text { Perse } \\
\text { ntase } \\
(\%)\end{array}$ \\
\hline 1 & Sangat & 10 & 18,18 \\
2 & mempertimbangkan & 22 & 40 \\
3 & Mempertimbangkan & 16 & 29,09 \\
4 & Biasa-biasa saja & 5 & 9,09 \\
5 & Tidak & 2 & 3,64 \\
& mempertimbangkan \\
& $\begin{array}{l}\text { Sangat tidak } \\
\text { mempertimbangkan }\end{array}$ & & \\
\hline \multicolumn{2}{|l|}{ Jumlah } & 55 & 100 \\
\hline
\end{tabular}

Sumber : Data Olahan

Dari tabel 15 diatas diketahui bahwa tanggapan responden dalam mempertimbangkan kualitas atau kondisi serta mutu barang terhadap perilaku pengambilan keputusan untuk membeli barang atau berbelanja di KUD Karya Agung dapat menunjukkan bahwa responden yang menjawab sangat mempertimbangkan sebanyak 10 orang atau $18,18 \%$, mempertimbangkan sebanyak 22 orang atau $40 \%$, biasa-biasa saja sebanyak 16 orang atau $29,09 \%$, tidak mempertimbangkan sebanyak 5 orang atau $9,09 \%$ dan sangat tidak mempertimbangkan sebanyak 2 orang atau $3,64 \%$.

Dengan demikian dapat disimpulkan bahwa tanggapan responden tersebut sebagian besar menjawab mempertimbangkan, berarti disini responden betul-betul memperhatikan dari kondisi serta mutu barang yang akan dibeli di koperasi.

Dan seterusnya untuk mengetahui tanggapan responden mengenai suasana tempat berbelanja terasa nyaman, bersih dan terjami aman dalam berbelanja di KUD Karya Agung dapat di lihat pada tabel berikut ini:

Tabel 16. Tanggapan responden mengenai suasana tempat berbelanja terasa nyaman, bersih dan terjamin aman terhadap pengambilan keputusan dalam membeli barang

\begin{tabular}{l} 
atau berbelanja di KUD Karya Agung \\
\hline No
\end{tabular}

Sumber : Data Olahan

Dari tabel 16 diatas diketahui bahwa tanggapan responden mengenai suasana tempat berbelanja terasa nyaman, bersih dan terjamin aman terhadap perilaku pengambilan keputusan untuk membeli barang atau berbelanja di KUD Karya Agung dapat menunjukkan bahwa responden yang menjawab sangat aman sebanyak 7 orang atau $12,73 \%$, aman sebanyak 8 orang atau $14,55 \%$, biasa-biasa saja sebanyak 14 orang atau $25,45 \%$, tidak aman sebanyak 11 orang atau $20 \%$ dan sangat tidak aman sebanyak 15 orang atau $27,27 \%$.

Dengan demikian dapat disimpulkan bahwa tanggapan responden mengenai suasana 
tempat berbelanja terasa nyaman, bersih dan terjamin aman terhadap pengambilan keputusan membeli barang atau berbelanja pada KUD Karya Agung, mayoritas responden merasa sangat tidak aman, karena dalam berbelanja para anggota merasa tidak tenang dengan kendaraan yang mereka bawa diparkir didepan koperasi tanpa ada juru parkir yang menjaga. Jadi ini merupakan salah satu ketidaknyamanan responden dalam membeli barang atau berbelanja pada KUD Karya Agung.

\section{KESIMPULAN}

a) Berdasarkan hasil penelitian faktor kebudayaan yang menentukan perilaku anggota koperasi dalam mengambik keputusan untuk membeli barang di KUD Karya Agung yaitu sudah sangat baik dimana anggota tidak terlalu memperhatikan mengenai budaya yang sering menjadi penyebab dari perubahan perilaku seseorang.

b) Perilaku anggota dalam keputusan membeli barang ditentukan juga oleh faktor lingkungan sosial dimana anggota koperasi lebih cenderung percaya sama keluarga dalam membeli barang pada KUD Karya Agung karena kebutuhan dan selera di dalam keluarga tidak jauh berbeda dan juga dorongan dari keluarga sangat kuat dalam menentukan berbelanja di koperasi demi memenuhi kebutuhan sehari-hari sesuai dengan persediaan barang yang ada di koperasi.

c) Berdasarkan perilaku anggota dalam keputusan membeli barang ditentukan juga oleh faktor sikap yang merupakan suatu perbuatan seseorang yang ingin berbelanja serta mengajak orang lain ikut serta dalam berbelanja ddi koperasi dia bergabung. Yang mana hal ini sangat besar pengaruhnya bagi koperasi karena demi menjaga kesetiaan sebagai anggota koperasi dan untuk meningkatkan omzet penjualan serta demi kemajuan koperasi.

d) Responden telah mempunyai kemampuan untuk tetap membeli barang di koperasi tetapi pada umumnya faktor psikologi dalam penelitian ini masih mengecewakan knsumen atau anggota karena masih keterbatasan sarana dan prasarana yang menunjang sehingga anggota akan merasa nyaman dan aman di dalam berbelanja di KUD Karya Agung.

\section{References}

Achmadi, Abu dan Cholid Narbuko, 2007. Metodologi Penelitian, Jakarta: PT. Bumi Aksara.

Anoeraga, P., \& Sudantoko, D. (2002).

Koperasi, Kewirausahaan dan Usaha Kecil. Jakarta: Rineka Cipta.

Gasperz, V. (1997). Konsep Vincent Penerapan Konsep Vincent Tentang Kualitas (Ahli Bahasa : Tim Penerjemah Yayasan Indonesia Emas). Jakarta: Yayasan Indonesia Emas dan PT. Gramedia Pustaka Utama, Jakarta.

Husein, U. (2003). Riset Pemasaran dan Perilaku Konsumen, Cetakan Ketiga. Jakarta: PT. Gramedia Pustaka Utama.

Istijanto, I. (2006). Riset Sumber Daya Manusia. Jakarta: PT. Gramedia Pustaka Utama.

Mangkunegara, A. A. (1998). Perilaku Konsumen. Bandung: Refika Aditama.

Sugiyono, 1999; Metode Penelitian Bisnis, CV. Alfabeta, Bandung.

Singarimbun, M., \& Efendi, S. (2001). Metode Penelitian Survei. Jakarta: LP3S.

Winarno, S. (1997). Metode Penelitian. Bandung: CV. Sinar Baru. 